\title{
Kepuasan Wisatawan Mancanegara dan Nusantara Ditinjau dari Keselamatan, Keamanan, Kesehatan dan Hygiene di Desa Wisata Indonesia
}

\author{
Soehardi ${ }^{1,}{ }^{\star}$, Bani Anhar ${ }^{2}$, Muhamad Heru Santoso ${ }^{3}$, Sujiyo Miranto ${ }^{4}$, Rusdi ${ }^{5}$ \\ ${ }^{1}$ Fakultas Ekonomi dan Bisnis, Universitas Bhayangkara Jakarta Raya; Jl. Raya Perjuangan, \\ Marga Mulya, Bekasi Utara, Jawa Barat 17121; telp.021-88955882, 889955883, e-mail: \\ soehardi@dsn.ubharajaya.ac.id \\ 2 Sekolah Tinggi IImu Ekonomi Balikpapan; Jl. Mayor Pol Zainal Arifin No. 166 RT 48 Sumber \\ Rejo Balikpapan Tengah Provinsi Kalimantan Timur 76124; telp.0542-8514883; e-mail: \\ banianhar@stiebalikpapan.ac.id \\ ${ }^{3}$ Graduate School, University of Immaculate Conception; 300 Margarita Village Rd, Buhangin, \\ Davao City, Philippines, telp +63822222320, email: hersant2016@gmail.com \\ ${ }^{4}$ Fakultas IImu Tarbiyah dan Keguruan, Universitas Islam Negeri Syarif Hidayatullah Jakarta; JI. \\ Ir. H. Juanda No. 95, Cemp. Putih Kecamatan Ciputat Timur Kota Tangerang Selatan, Provinsi \\ Banten 15412, telp 021-4894909; e-mail: suijyo@uinjkt.ac.id \\ ${ }^{5}$ Fakultas Matematika dan Ilmu Pengetahuan Alam, Universitas Negeri Jakarta; J. \\ Rawamangun Muka Raya Kecamatan Pulau Gadung Jakarta Timur DKI Jakarta 13220, telp \\ 021-4894909; e-mail: rusdi@unj.ac.id \\ * Korespondensi: e-mail: soehardi@dsn.ubharajaya.ac.id \\ Submitted: 21/12/2020; Revised: 07/01/2021; Accepted: 13/01/2021; Published: 15/01/2021
}

\begin{abstract}
The purpose of this study was to determine the satisfaction of foreign and domestic tourists in terms of safety, security, health and hygiene in the Tourism Village, Indonesia. The study population was all foreign and domestic tourists who visited Tourism Villages, Indonesia from January to December 2019 and the sample used was cluster random sampling, with a total of 91 respondents. Quantitative research methods were used in this study with construct validity and reliability analysis, composite reliability, cronbach's alpha, average variance extracted, path coefficient and $R$ square. There is an effect of health and hygiene on the satisfaction of foreign and domestic tourists. The better the health and hygiene, the greater the satisfaction of foreign and domestic tourists. Accessibility to drinking water and sanitation is the main indicator of health and hygiene when compared with other indicators such as: availability of the number of doctors and nurses, hospital bed facilities and risk of disease. There is an effect of safety and security on the satisfaction of foreign and domestic tourists. The better safety and security, the greater the satisfaction of foreign and domestic tourists. The accessibility of tourist destinations is the main indicator of safety and security compared to other indicators such as: friendly and kind employees, tourist village places to protect goods belonging to foreign and domestic tourists, clarity of safety and security signs and directions, walks during the day safer than at night.
\end{abstract}

Keywords: Health and Hygiene, Safety and Security, Tourism Villages

\section{Abstrak}

Tujuan penelitian ini adalah untuk mengetahui kepuasan wisatawan mancanegara dan nusantara ditinjau dari keselamatan, keamanan, kesehatan dan hygiene di Desa Wisata, Indonesia. Populasi penelitian adalah seluruh wisatawan mancanegara dan nusantara yang berkunjung ke Desa-Desa Wisata, Indonesia bulan Januari hingga Desember 2019 dan sample yang digunakan adalah cluster random sampling diperoleh responden berjumlah 91 . Metode penelitian kuantitatif digunakan dalam penelitian ini dengan analisis construct validity and 
reliability, composite reliability, cronbach's alpha, average variance extracted, path coefficient and $R$ square. Ada pengaruh kesehatan dan hygiene terhadap kepuasan wisatawan mancanegara dan nusantara. Semakin baik kesehatan dan hygiene, maka semakin meningkat kepuasan wisatawan mancanegara dan nusantara. Aksesabilitas ke air minum dan sanitasi merupakan indikator utama kesehatan dan hygiene apabila dibandingkan dengan indikator lainnya seperti: ketersediaan jumlah dokter dan perawat, fasilitas tempat tidur rumah sakit dan resiko terkena penyakit. Ada pengaruh keselamatan dan keamanan terhadap kepuasan wisatawan mancanegara dan nusantara. Semakin baik keselamatan dan kesamanan, maka semakin meningkat kepuasan wisatawan mancanegara dan nusantara. Aksesabilitas tujuan wisata merupakan indikator utama keselamatan dan keamanan dibandingkan dengan indikator lainnya seperti: karyawan yang bersahabat dan baik, tempat desa wisata melindungi barangbarang milik wisatawan mancanegara dan nusantara, kejelasan rambu-rambu dan arahan keselamatan dan keamanan, jalan-jalan di siang hari lebih aman dibandingkan malam hari.

Kata kunci: Kesehatan dan Hygiene, Keselamatan dan Keamanan, Desa Wisata

\section{Pendahuluan}

Desa wisata dan pariwisata digital merupakan salah satu program prioritas Kementerian Pariwisata dan Ekonomi Kreatif Republik Indonesia sejak tahun 2017 hingga sekarang ini. Desa wisata merupakan daerah tujuan wisata bagi wisatawan mancanegara dan nusantara yang ingin "back to the nature" atau kembali ke pemandangan lingkungan alam sekitarnya yang indah dengan menghirup udara yang segar dan bersih serta mengurangi frekuensi kunjungan ke tempat-tempat yang banyak dikunjungi oleh orang lain. Desa wisata mengutamakan wisata alam pertanian, perikanan dan perkebunan, sosial budaya, keunikan atau karakteristik lokal yang ada di daerah-daerah di Indonesia.

Desa wisata telah menjadi tren yang menarik bagi para wisatawan mancanegara dan nusantara sejak 2017 hingga sekarang ini. Prioritas pemerintah Indonesia ini membuat stakeholders yang terdiri dari pelaku bisnis, masyarakat dan pemerintah daerah saling bekerja sama untuk memajukan desa-desa wisata lebih bersahabat dengan alam dengan memperhatikan sosial budaya dan kearifan local masyarakat sehingga desa wisata memiliki potensi untuk dikembangkan dan memiliki daya tarik yang tinggi bagi wisatawan mancanegara dan nusantara. Hal ini membuat semangat perusahaan-perusahaan tour and travel dan perhimpunan hotel dan restoran untuk memasarkan produk dan jasa berupa paket-paket wisata di dalam negeri dan luar negeri baik secara online maupun offline.

Indonesia adalah negara dari Sabang hingga Merauke yang memiliki keanekaragaman flora, fauna, budaya, bahasa dan karakteristik lokal. Desa-desa wisata mulai ditumbuhkembangkan bukan hanya terbatas pada potensi lingkungan alam sekitarnya berupa sungai, bukit, gunung namun juga diperlukan investasi pembangunan infrastruktur jalan raya, information and communication technolog, Beberapa potensi lainnya di desa-desa wisata juga belum maksimal diberdayakan adalah public and private partnership atau kemitraan bersama antara pemerintah pusat, pemerintah daerah dan perusahaan-perusahaan swasta untuk meningkatkan jumlah usaha mikro, kecil dan menengah. Upaya yang terus menerus dilakukan ini diharapkan dapat meningkatkan daya saing destinasi desa-desa wisata 
Desa wisata menjadi tren menarik dalam upaya pengembangan daerah tujuan wisata alternative di Indonesia sejak 2017 hingga sekarang ini. Dari tahun ke tahun, jumlah desa wisata di Indonesia terus bertumbuh secara bertahap (Liliyah \& Rahayu, 2020). Menurut Badan Pusat Statistik terdata 2,07\% atau 1.734 desa wisata dari total 83.931 desa di Indonesia tahun 2018. Kementerian Desa, Pembangunan Daerah Tertinggal dan Transmigrasi telah mentargetkan desa wisata akan bertambah menjadi 10.000 pada tahun 2021. Global Green Destinations Days (GGDD) telah membuat pengumuman tentang Top 100 Destinasi Berkelanjutan di Dunia tahun 2019 diantaranya terdapat 4 (empat) desa wisata, Indonesia yaitu Desa Nglanggeran di Kabupaten Gunungkidul (DIY), Desa Pentingsari di Kabupaten Sleman (DIY), Desa Pemuteran di Kabupaten Buleleng (Bali) dan Desa Adat Penglipuran di Kabupaten Bangli (Bali).

Keselamatan, keamanan, kesehatan dan hygiene merupakan beberapa variable daya saing perjalanan dan pariwisata sebagai beberapa unggulan platform yang dibuat oleh World Economic Forum. Beberapa variabel ini berfungsi sebagai salah satu alat pengukuran strategis bagi pemerintah dan perusahaan-perusahaan swasta dalam membuat kebijakan perencanaan strategis dan pengambilan keputusan dalam upaya memajukan pengembangan sektor pariwsata di setiap negara dan juga di setiap daerahnya masing-masing. Selain itu, dapat digunakan para stakeholders dalam memahami dan mengantisipasi tren dan risiko yang muncul dalam perjalanan dan pariwisata baik di tingkat lokal, nasional, regional dan global.

Konektivitas transportasi laut dan udara, pemasaran digital, aksesabilitas destinasi dan keterbukaan lalu lintas barang dan jasa internasional semakin meningkat dalam konteks global demi keselamatan, keamanan, kesehatan dan Hygiene bagi wsiatawan mancanegara dan nusantara tetap terjaga dengan baik dan benar. Begitu pula perlu perbaikan infrastruktur transportasi laut dan udara menunjukkan peningkatan yang signifikan pada kapasitas rute, jumlah pelayaran dan maskapai penerbangan dalam upaya menyediakan pelayananan yang prima kepada wisatawan mancanegara dan nusantara di masing-masing negara. Pemasaran digital melalui website, email dan media sosial seperti facebook, twitter, instagram dan youtube perlu terus didukung dan dilengkapi fasilitas jaringan internet di Desa Wisata, Indonesia.

Daya saing Indonesia berdasarkan tingkat kepuasan wisatawan mancanegara dan nusantara terhadap keselamatan, keamanan, kesehatan dan Hygiene menurut World Economic Forum dari tahun ke tahun menunjukkan peningkatan tren kearah positif. Pembangunan pariwisata Indonesia secara signifikan pada umumnya dan peningkatan daya saing ke arah yang positif pula pengembangan desa-desa wisata di daerah-daerah, Indonesia. Beberapa faktor yang menentukan daya saing desa wisata di Indonesia antara lain: keselamatan, keamanan, kesehatan dan Hygiene.

Menurut (Badan Nasional Sertifikasi Profesi, 2020) bahwa karyawan yang bekerja di industri pariwisata sebaiknya memiliki sertifikat profesi. Begit pula, karyawan asing yang bekerja di industri pariwisata sebaiknya juga memiliki sertifikasi profesi dan memenuhi persyaratan peraturan hukum yang berlaku di Indonesia. (Kementerian Pariwisata dan Kebudayaan, 2011) 
telah mengeluarkan Peraturan Nomor: KM.18/HM.001/MKP/2011 tentang Program Nasional Pemberdayaan Masyarakat Mandiri Pariwisata. Desa wisata adalah bentuk integrasi antara atraksi, akomodasi dan fasilitas pendukung berbasis budaya yang ramah tamah dan sumber daya lokal untuk menyerap tenaga kerja dan membuka peluang usaha di desa-desa. Desa wisata memiliki keunikan lingkungan alam, budaya daerah dan kearifan lokal, potensi ekonomi pertanian dan perikanan,

Tujuan desa wisata adalah meningkatkan kemampuan kreativitas, berusaha dan berkarya masyarakat, membangun kemitraan instnasi pemerintah dan swasta dalam upaya akselerasi pembangunan desa wisata di Indonesia (Kementerian Pariwisata dan Kebudayaan, 2011). Pendekataan desa wisata adalah pembangunan kepariwisataan berbasis pemberdayaan masyarakat, keberpihakan kepada masyarakat miskin, desentralisasi, partisipatif, penguatan kapasitas usaha desa wisata, pembangunan desa wisata terintegrasi dan berkelanjutan. Strategi pengembangan desa wisata berbasis gugusan (cluster) untuk meningkatkan daya saing produk dan jasa serta peningkatan fasilitas fisik seperti hotel, resort, bangunan sejarah dan fasilitas non fisik seperti kearifan local, budaya dan kekhasan desa, pelatihan-pelatihan manajemen pariwisata, kuliner, kerajinan dan bahasa. Beberapa contoh desa wisata seperti Malasari Bogor, Cibuntu Kuningan, Gamplong Yogyakarta, Kasongan Yogyakarta, Pentingsari Yogyakarta, Nglanggeran Yogyakarta, Ponggok Klaten, Pujon Kidul Malang, Tamansari Banyuwangi, Penglipuran Bali, Ubud Bali, Pemuteran Bali, Sungai Nyalo Sumatera Barat, Kubu Gadang Padang, Teluk Meranti Riau, Tiwingan Kalimantan, Bontagula Kalimantan Timur, Namu Sulawesi Tenggara, Waturaka Ende, dan lain-lain.

Definisi wisatawan mancanegara adalah seseorang yang melakukan kegiatan kunjungan dengan menggunakan transportasi udara, laut dan darat ke suatu negara yang dituju di luar negara tempat tinggalnya dengan tujuan bisnis, personal atau tujuan pribadi lainnya, kecuali bekerja (Biro Pusat Statistik, 2020). Tujuan bisnis seperti menghadiri pertemuan pelatihan, seminar, konferensi dan kongres internasional, pameran dagang, konser dan pertunjukan. Sedangkan tujuan pribadi seperti berlibur, rekreasi, mengunjungi teman dan keluarga, shopping, kesehatan, olahraga dan keagamaan.

Wisatawan nusantara atau wisatawan dalam negeri adalah seseorang yang melakukan kegiatan kunjungan dengan menggunakan transportasi udara, laut dan darat ke suatu tempat dengan tujuan bisnis, personal atau tujuan pribadi lainnya masih dalam negaranya. Tujuan bisnis seperti menghadiri pertemuan pelatihan, Focus Group Discussion (FGD), workshop, seminar, konferensi atau kongres nasional, pameran dagang, konser atau pertunjukan. Sedangkan tujuan pribadi melakukan kegiatan kunjungan seperti berlibur, rekreasi, mengunjungi teman dan keluarga, seni, budaya, shopping, kesehatan, olahraga atau keagamaan.

Indeks Daya Saing Perjalanan \& Pariwisata berdasarkan Keselamatan dan Keamanan terdiri dari: keselamatan dan keamanan adalah faktor penting yang menentukan daya saing industri T\&T suatu negara (World Economic Forum, 2019). Wisatawan cenderung terhalang 
untuk bepergian ke negara atau wilayah berbahaya, sehingga kurang menarik untuk mengembangkan sektor T\&T di tempat-tempat tersebut. Di sini kami memperhitungkan mahalnya kejahatan umum dan kekerasan serta terorisme, dan sejauh mana layanan polisi dapat diandalkan untuk memberikan perlindungan dari kejahatan.

Keunggulan kompetitif berdasarkan tingkat konsentrasi tindakan pengamanan di fasilitas akomodasi yang diukur dengan Indeks Herfindahl - Hirschman, terdiri dari alat pemadam kebakaran, CCTV di luar tempat tinggal, CCTV di tempat-tempat umum, alarm keamanan, keamanan 24 jam, transportasi antar jemput bandara, elevator, parkiran kendaraan, kamar bebas alergi, resepsionis 24 jam, kotak deposit keamanan, pelayanan tamu dan detektor asap (Nagaj \& Žuromskaitè, 2020).

Persepsi turis tentang indikator keselamatan dan keamanan terdiri dari: berjalan-jalan selama waktu siang, berjalan-jalan selama waktu malam, menggunakan transportasi umum, penyebrangan jalan dan perasaan tentang lingkungan disekitarnya (Amir et al., 2015). Persepsi turis tentang keselamatan dan keamanan adalah wisata di siang hari, jumlah penerangan malam hari, aksesibilitas destinasi, tempat wisata dan tempat kunjungan, transportasi, kondisi lalu lintas, kualitas jalan, jembatan, layanan utilitas, area akomodasi, penawaran belanja yang adil, penjaga pantai dan layanannya dan keselamatan perairan (Manui \& Wongsai, 2017).

Indeks Daya Saing Perjalanan \& Pariwisata Subindeks Lingkungan Kondusif menangkap kondisi umum yang diperlukan untuk beroperasi di suatu negara dan mencakup Kesehatan dan Kebersihan (6 indikator): Kesehatan dan kebersihan juga penting untuk daya saing T\&T (World Economic Forum, 2019). Akses ke air minum dan sanitasi yang lebih baik penting untuk kenyamanan dan kesehatan para pelancong. Jika wisatawan jatuh sakit, sektor kesehatan negara harus dapat memastikan bahwa mereka dirawat dengan baik, yang diukur dari ketersediaan dokter dan tempat tidur rumah sakit. Selain itu, tingginya prevalensi HIV dan malaria dapat berdampak pada produktivitas tenaga kerja T\&T dan berperan dalam mencegah wisatawan berkunjung ke suatu negara.

Indikator kesehatan dan hygiene adalah kepadatan dokter per 1.000 penduduk, akses pada peningkatan sanitasi. akses pada peningkatan air minum dan tempat tidur pasien di rumah sakit (Jovanović et al., 2015). Kepadatan dokter per 1.000 penduduk sebagai indikator utama kesehatan dan hygiene dibandingkan indikator lainnya, seperti akses pada peningkatan sanitasi akses pada peningkatan air minum dan tempat tidur pasien di rumah sakit.

Kepuasan wisatawan dipegaruhi oleh beberapa faktor seperti perjamuan, atraksi tujuan wisata, suasana lingkungan, akomodasi, makanan dan minuman, jasa transportai dan perbelanjaan (Ramasamy, 2013). Indikator kepuasan wisatawan adalah, sebagai berikut perjalanan kembali beberapa kali, pelayanan yang baik, ketegasan pilihan, kepuasan, rekomendasi, persepsi pengalaman, budaya dan pengalaman alam, minat dan diferensiasi pengalaman (Castro et al., 2017). 


\section{Metode Penelitian}

Populasi adalah seluruh wisatawan mancanegara dan nusantara yang berkunjung ke Indonesia pada tahun 2019. Sampel yang digunakan adalah cluster random sampling berjumlah 91 orang. Metode penelitian yang digunakan adalah metode penelitian kuantitatif dengan analisis construct reliability and validity, cronbach's alpha, rho_A, average variance axtracted, path coefficients and $R$ square dengan menggunakan software Partial Least Square (PLS).

\section{Hasil dan Pembahasan}

Jumlah responden di Desa Wisata, Indonesia tercatat 91 orang terdiri dari 31 wanita dan 60 laki-laki. Pendidikan responden lulusan SMA/SMK berjumlah 27 orang, Sarjana berjumlah 51 orang, Masteral dan Dokoral berjumlah 13 orang. Umur responden dibawah 25 tahun berjumlah 39, umur 25 - 50 tahun berjumlah 36 dan umur diatas 50 tahun berjumlah 16 orang. Ditinjau dari kewarganegaraan responden terdiri dari: warga negara asing berjumlah 43 orang dan warga Negara Indonesia berjumlah 48 orang

Tujuan wisata ke Desa Wisata, Indonesia menurut responden adalah kenyamanan 28, mengunjungi teman dan keluarga 24, bisnis 26 dan pendidikan 13. Pengaturan perjalanan menurut responden terdiri dari: diatur sendiri 54, diatur agen perjalanan 32 dan lainnya 5. Pengaturan perjalanan menurut responden terdiri dari: ditentukan oleh dirinya sendiri sebanyak 25 , pasangan 39 , sekelompok 3 orang sebanyak 10 dam sekolompok lebih dari 4 orang sebanyak 17 orang.

Ditinjau dari banyaknya kunjungan ke Desa Wisata adalah kunjungan pertama sebanyak 36 orang atau 39,56\%, kunjungan kedua sebanyak 37 orang atau $40,66 \%$ dan kunjungan ketiga atau lebih sebanyak 18 orang atau $19,78 \%$. Ditinjau dari lama tinggal responden terdiri dari: 1 malam sejumlah 5 atau 5,49\%, 2 malam sejumlah 35 atau 38,46\%, 3 malam sejumlah 28 orang atau $30,77 \%$ dan 4 malam sejumlah 23 orang atau $25,27 \%$.

Tabel 1. Sebaran Desa Wisata di Indonesia Tahun 2018

\begin{tabular}{cr}
\hline Lokasi Desa Wisata & Jumlah Desa Wisata \\
\hline Sumatera & 355 \\
\hline Jawa dan Bali & 857 \\
\hline Kalimantan & 117 \\
\hline Sulawesi & 119 \\
\hline Nusa Tenggara & 189 \\
\hline Papua & 74 \\
\hline Maluku & 23 \\
\hline Total & 1.734
\end{tabular}

Sumber: (Kusubandio \& Tanoesoedibjo, 2020) dan (Fanani \& Maryati, 2019)

Pendapat tentang isu-isu tentang keselamatan dan keamanan wisatawan di Desa Wisata, Indonesia terdiri dari: response kecepatan petugas terhadap keselamatan dan keamanan sejumlah 36 orang atau $39,56 \%$, ketersediaan fasilitas keselamatan dan keamanan 
sejumlah 29 atau $31,87 \%$ dan keramahtamahan atau persahabatan penduduk setempat terhadap wisatawan mancanegara dan nusantara sebanyak 26 orang atau 28,57\%. Fasilitas keselamatan dan keamanan di Lokasi Atraksi, Desa Wisata, Indonesia menurut wisatawan mancanegara dan nusantara terdiri dari: kamera CCTV, sistem alarm, tanda dan petunjuk arah, keamanan kotak deposit dan penjaga keamanan.

Pendapat lainnya tentang isu-isu kesehatan dan hygiene adalah 61 responden atau 67,03\% memilih tujuan wisata di Desa Wisata yang banyak memiliki dokter dan fasilitas rumah sakit apabila dibandingkan dengan 30 responden atau $32,97 \%$ yang mengatakan bahwa wisatawan nusantara tidak memilih tujuan wisata di Desa Wisata yang banyak memiliki dokter dan fasilitas rumah sakit.

Tabel 2. Data Wisatawan Mancanegara dan Nusantara Tahun 2018, 2019 dan 2020

\begin{tabular}{|c|c|c|c|}
\hline Wisatawan & 2018 & 2019 & 2020 \\
\hline \multirow[t]{2}{*}{ Wisatawan Mancanegara } & 15.810 .000 & 16.110 .000 & 10.000 .000 \\
\hline & & & (Target) \\
\hline \multirow[t]{2}{*}{ Wisatawan Nusantara } & 303.400 .000 & 275.000 .000 & 130.000 .000 \\
\hline & & & (Target) \\
\hline
\end{tabular}

Sumber: (Kemenparekraf Republik Indonesia, 2020)

\subsection{Construct Realiability and Validity}

Berdasarkan tabel 3 gambar 1, 2, 3 dan 4 dengan menggunakan software Partial Least Square (PLS) bahwa uji validitas dan reliabilitas dapat digunakan dengan beberapa cara antara lain: composite reliability, cronbach's alpha, average variance extracted (AVE) and rho_A. Pada analisis composite reliability tentang keselamatan dan keamanan, kesehatan dan hygiene serta kepuasan wisatawan mancanegara dan nusantara diperoleh nilai $\geq 0,84$ dapat dikatakan reliabel. Pada analisis cronbach's alpha tentang tentang keselamatan dan keamanan, kesehatan dan hygiene serta kepuasan wisatawan mancanegara dan nusantara diperoleh nilai $\geq 0,77$ dapat dikatakan reliabel. Pada analisis rho_A tentang tentang keselamatan dan keamanan, kesehatan dan hygiene serta kepuasan wisatawan mancanegara dan nusantara diperoleh nilai $\geq 0,79$ dapat dikatakan reliable. Pada analisis Average Variance Extracted (AVE) tentang tentang keselamatan dan keamanan, kesehatan dan hygiene serta kepuasan wisatawan mancanegara dan nusantara diperoleh nilai $\geq 0,53$ dapat dikatakan valid. Pada tabel 3 menjelaskan tentang Construct Realiability and Validity.

Tabel 3. Construct Realiability and Validity

\begin{tabular}{|c|c|c|c|c|c|c|c|}
\hline \multirow[t]{2}{*}{ Matrix } & 期等 Cronbach's Alpha & 拝萃 rho_A & 挰莘 & Composite Reliability & 擭 Average Varian & e Extracted (... & Copy to Clipboard: \\
\hline & & \multicolumn{2}{|c|}{ Cronbach's Alpha } & rho_A & Composite Reliability & \multicolumn{2}{|c|}{ Average Variance Extracted (AVE) } \\
\hline \multicolumn{2}{|c|}{ Health and Hygiene } & \multicolumn{2}{|c|}{0.778} & 0.793 & \multicolumn{2}{|l|}{0.848} & 0.530 \\
\hline \multicolumn{2}{|c|}{ Safety and Security } & \multicolumn{2}{|c|}{0.806} & 0.847 & \multicolumn{2}{|l|}{0.864} & 0.565 \\
\hline \multicolumn{2}{|l|}{ Tourists } & \multicolumn{2}{|c|}{0.804} & 0.806 & \multicolumn{2}{|l|}{0.865} & 0.562 \\
\hline
\end{tabular}

Sumber: Hasil Pengolahan Data (2020) 
Pada gambar 1, 2, 3 dan 4 menjelaskan tentang dan Average Variance Extracted (AVE), Composite Reliability, Cronbach's Alpha, Rho_A

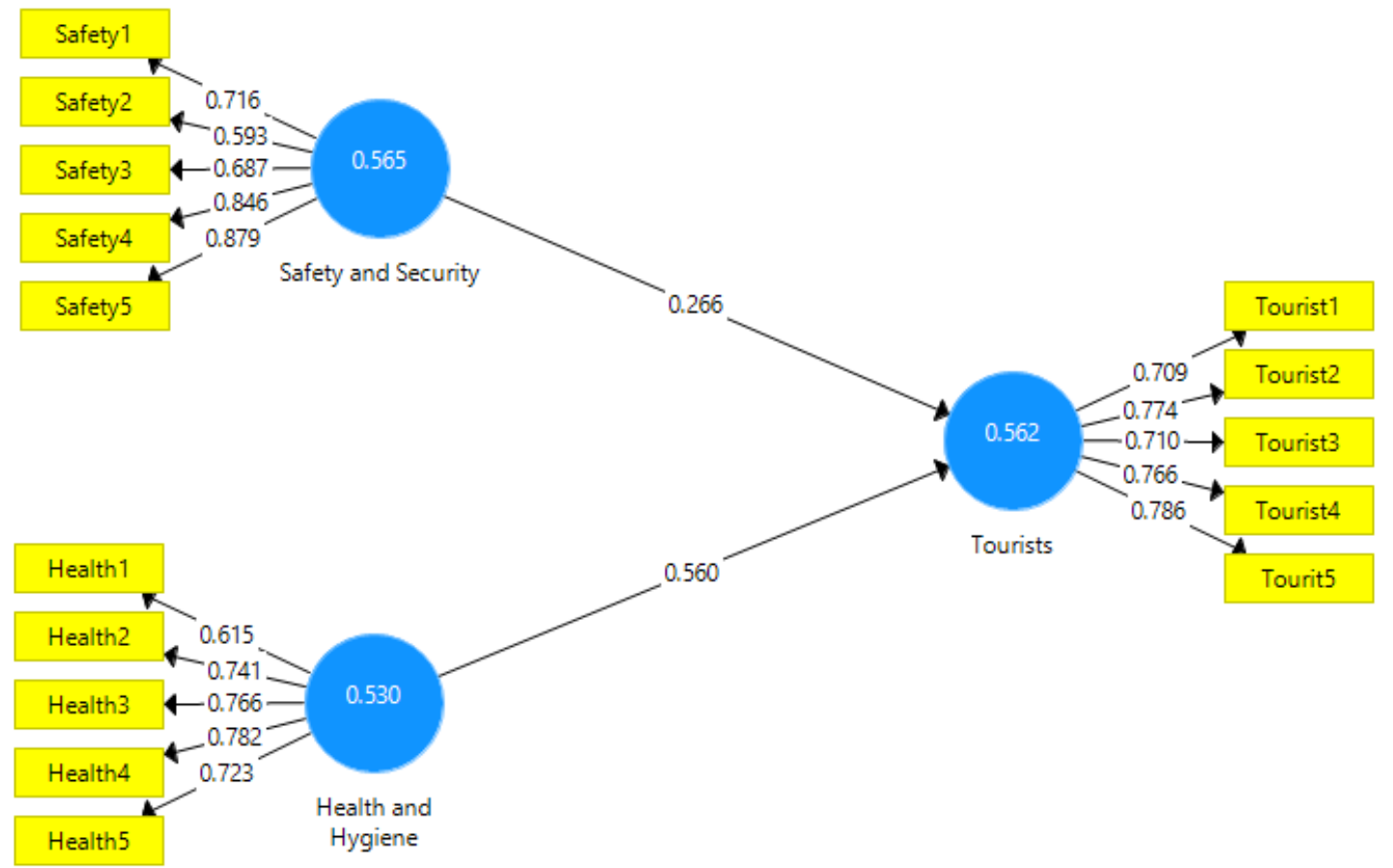

Sumber: Hasil Penelitian (2020)

Gambar 1. Average Variance Extracted (AVE)

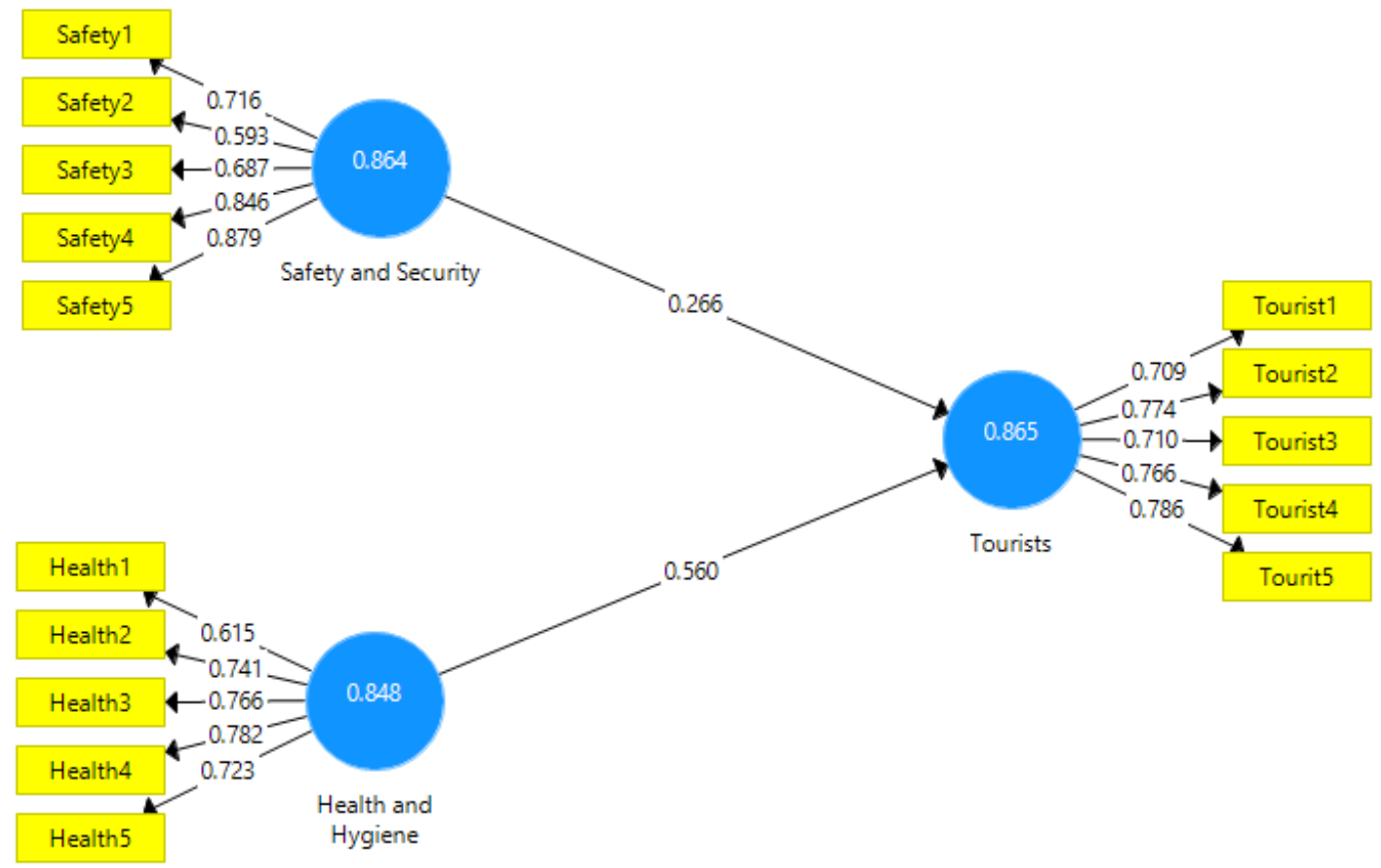

Sumber: Hasil Penelitian (2020)

Gambar 2. Composite realiability 


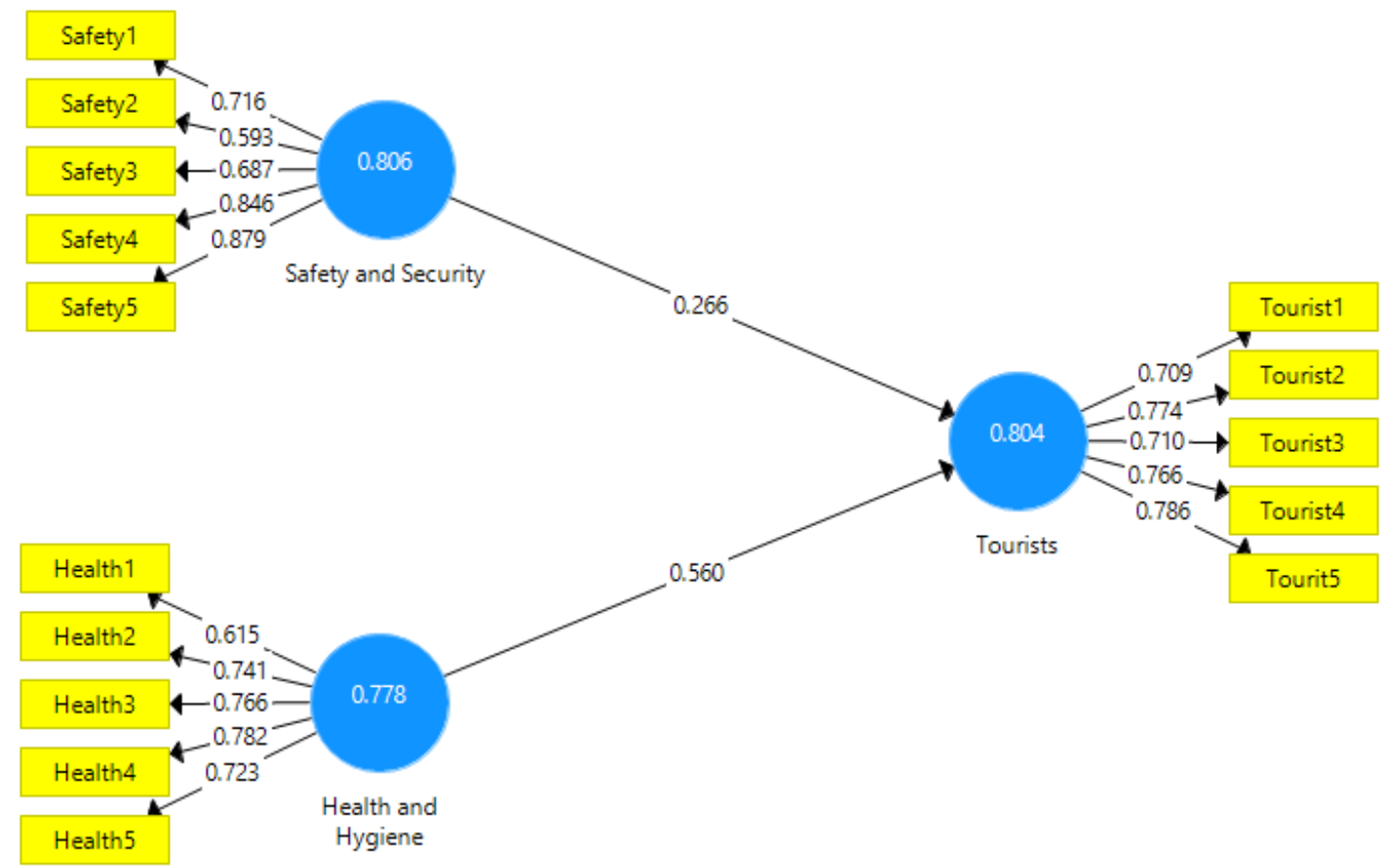

Sumber: Hasil Penelitian (2020)

Gambar 3. Cronbach's alpha

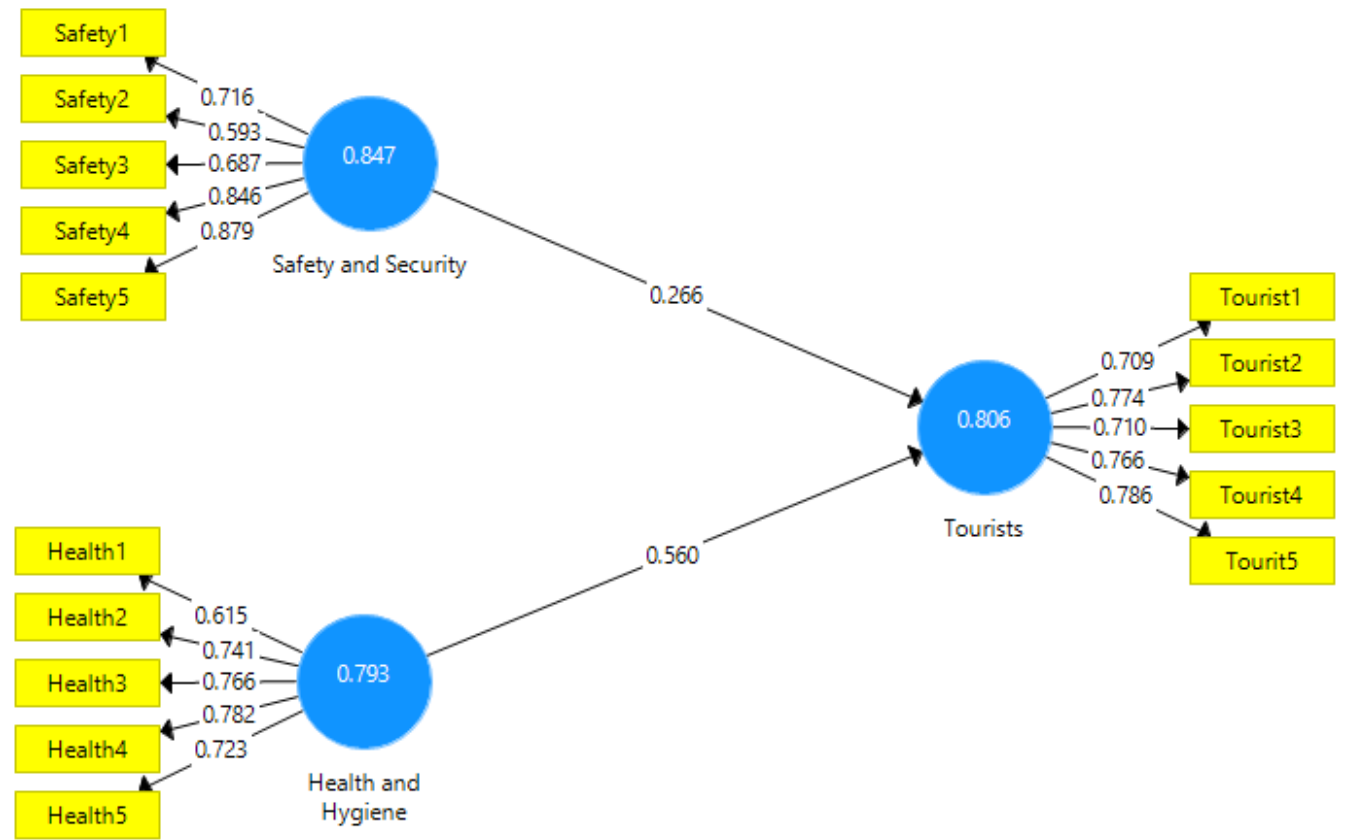

Sumber: Hasil Penelitian (2020)

\section{Gambar 4. Rho_A}

\subsection{Path Coefficients}

Berdasarkan tabel 4 dan gambar 5 uji t dan $P$ values menghasilkan hipotesis pertama bahwa $t$ hitung $(5,009) \geq \mathrm{t}$ tabel $(1,990)$ dan nilai $P$ hitung $(0,000) \leq P$ tabel $(0,05)$, dapat diartikan ada pengaruh kesehatan dan hygiene terhadap kepuasan wisatawan mancanegara dan nusantara. Hipotesis kedua bahwa t hitung $(2,129) \geq \mathrm{t}$ tabel $(1,990)$ dan nilai $\mathrm{P}$ hitung 
$(0,034) \leq \mathrm{P}$ tabel $(0,05)$, dapat diartikan ada pengaruh keselamatan dan keamanan terhadap kepuasan wisatawan mancanegara dan nusantara. Pada tabel 4 menjelaskan tentang uji t dan $P$ values.

Tabel 4. Path Coefficients

\section{Path Coefficients}

\begin{tabular}{|c|c|c|c|c|c|c|c|}
\hline \multirow[t]{2}{*}{ Mean, STDEV, T-Values, P.V.... } & Confidence Intervals & Confidencel & tervals Bias $\mathrm{C}_{\mathrm{m}}$ & 粗 Samples & Copy to Clipboard: & Excel Format & RForn \\
\hline & Original Sample (0) & Sample Mean (M) & Standard Der & idtion (STDEV) & TStatistics (10/STDE & & Values \\
\hline Heath and Hygiene-> Tourists & 0.560 & 0.565 & & 0.112 & & 0009 & 0.000 \\
\hline Safety and Security-> Tourists & 0.266 & 0.270 & & 0.125 & & 129 & 0.034 \\
\hline
\end{tabular}

Pada gambar 5 menjelaskan tentang $t$ values dan $P$ values.

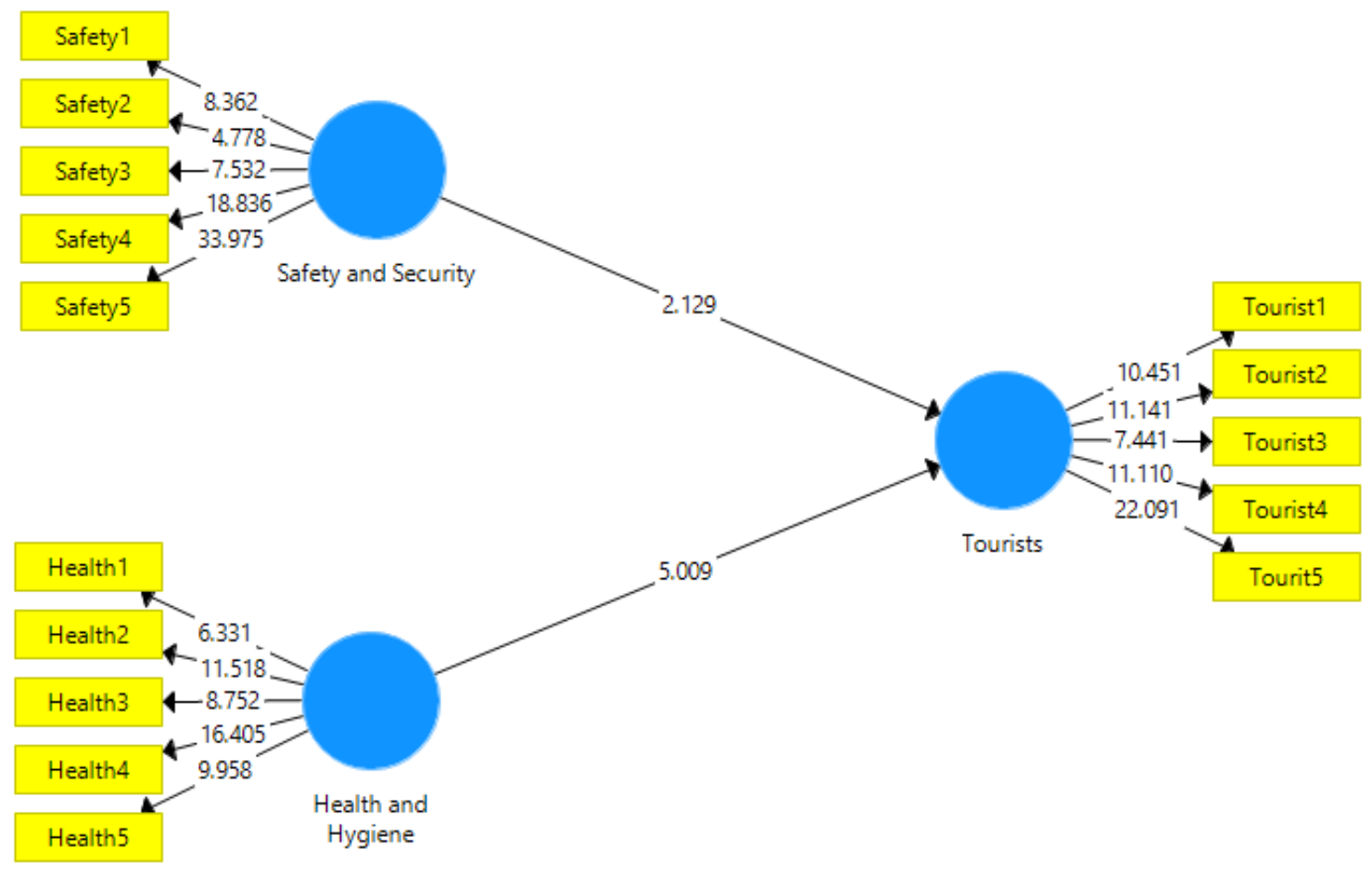

Sumber: Hasil Penelitian (2020)

\section{Gambar 5. $T$ Value}

\section{3. $R$ Square}

Berdasarkan tabel 5 dan gambar 6 koefisen determinasi atau $R$ square tentang wisatawan mancanegara dan nusantara sebesar 0,593, artinya variabel laten wisatawan mancanegara dan nusantara berpengaruh $59,30 \%$ dan $40,70 \%$ dipengaruhi oleh variabel laten lainnya. Pada tabel 5 menjelaskan tentang $R$ square. 
Tabel 5. $R$ Square

\section{R Square}

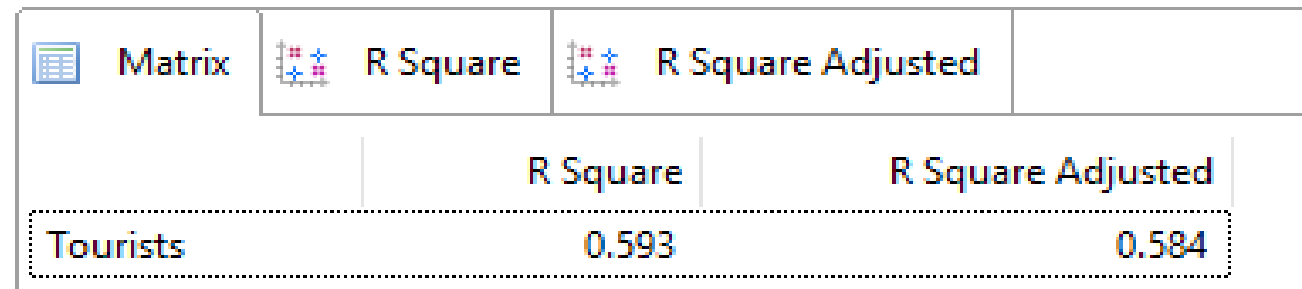

Sumber: Hasil Pengolahan Data (2020)

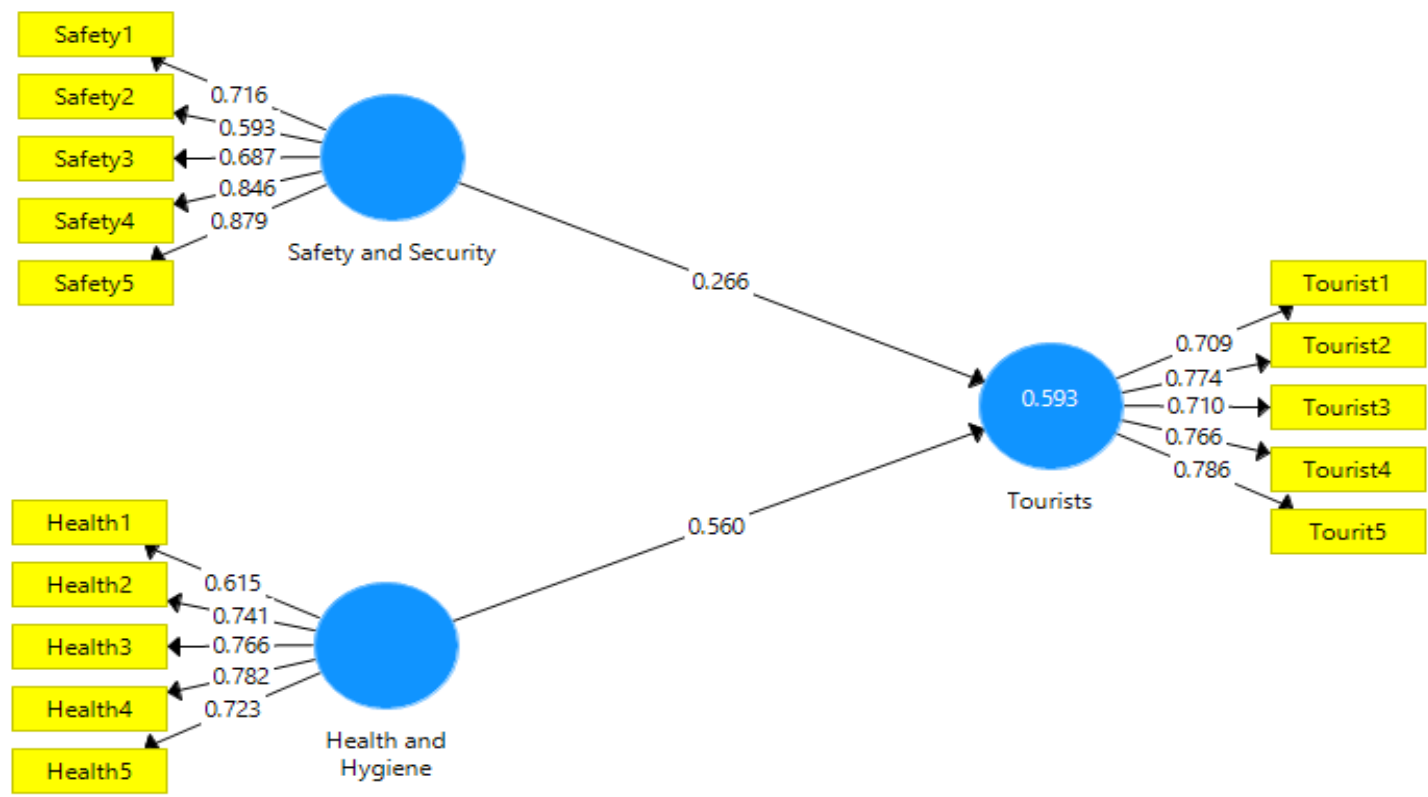

Sumber: Hasil Penelitian (2020)

Gambar 6. R Square

\subsection{Kesehatan dan Hygiene terhadap Kepuasan Wisatawan Mancanegara dan Nusantara}

Hipotesis pertama bahwa thitung $(5,009) \geq t$ tabel $(1,990)$ dan nilai $P$ hitung $(0,000) \leq P$ tabel $(0,05)$, dapat diartikan ada pengaruh kesehatan dan hygiene terhadap kepuasan wisatawan mancanegara dan nusantara. Semakin baik kesehatan dan hygiene, maka semakin meningkat kepuasan wisatawan mancanegara dan nusantara.

Penelitian ini mendukung penelitian sebelumnya yang dilakukan oleh (World Economic Forum, 2019) tentang the Travel and Tourism Competitiveness Index bahwa Spanyol, Perancis, German, Jepang, Amerika Serikat, Inggris, Australia, Italia, Canada, Swiss, Austria, Portugasl, China, Hongkong, Belanda, Korea Selatan, Singapura, Selandia Baru, Mexico dan Swedia menduduki top 20 ranking berdasarkan salah satu indikator kesehatan dan hygiene.

Penelitian ini mendukung penelitian sebelumnya yang dilakukan oleh (Jovanović et al., 2015) dengan judul "Health and Hygiene Importance for the Improvement of Tourism Sector Competitiveness in Serbia and the South-Eastern Europe Countries" yang mengatakan bahwa kesehatan dan kebersihan sangat penting bagi banyak wisatawan yang memilih tujuan dan 
berencana mengunjungi satu negara. Berdasarkan kesehatan dan hygiene, wisatawan lebih memilih berkunjung ke Hongaria, Bulgaria, Kroasia dan Slovenia dibandingkan Serbia.

Penelitian ini juga mendukung penelitian yang dilakukan oleh penulis bahwa 49 responden atau $53,85 \%$ mengatakan bahwa wisatawan mancanegara dan nusantara merasa puas terhadap kesehatan dan hygiene di Desa-Desa Wisata, Indonesia. Sebaliknya 42 responden atau 46,15\% mengatakan bahwa wisatawan mancanegara dan nusantara tidak merasa puas terhadap kesehatan dan hygiene di Desa-Desa Wisata, Indonesia

\subsection{Keselamatan dan Keamanan terhadap Kepuasan Wisatawan Mancanegara dan Nusantara}

Hipotesis kedua bahwa t hitung $(2,129) \geq t$ tabel $(1,990)$ dan nilai $P$ hitung $(0,034) \leq P$ tabel $(0,05)$, dapat diartikan ada pengaruh keselamatan dan keamanan terhadap kepuasan wisatawan mancanegara dan nusantara.

Penelitian ini mendukung penelitian sebelumnya yang dilakukan oleh (Amir et al., 2015) dengan judul "Sustainable Tourist Environment: Perception of International Women Travelers on Safety and Security in Kuala Lumpur" yang mengatakan bahwa persepsi turis positif tentang keselamatan dan keamanan di Malaysia. Penelitian ini juga mendukung penelitian sebelumnya yang dilakukan oleh (Manui \& Wongsai, 2017) dengan judul "Tourists 'Perceptions on Safety and Security : a Case Study of Phuket Island of Thailand" yang mengatakan bahwa para wisatawan dari negara-negara Oceania dan Eropa merasa lebih aman dengan kegiatan wisata dibandingkan dengan mereka yang berasal dari negara-negara Asia. Semakin sering mereka mengunjungi destinasi tersebut wisatawan semakin kurang nyaman dengan lalu lintas dan keamanan jalan raya di pulau tersebut.

Penelitian ini juga mendukung penelitian sebelumnya yang dilakukan oleh (Imbeah \& Bujdoso, 2018) dengan judul "Tourist safety and security in the Central Region of Ghana overview and case study" yang mengatakan bahwa 473 dari 550 responden atau 86,00\% menginginkan keselamatan dan keamanan wisatawan di Ghana. (OA, 2017) dengan judul "Impact of Safety Issues and Hygiene Perceptions on Customer Satisfaction: A Case Study of Four and Five Star Hotels in Aqaba, Jordan" yang mengatakan bahwa Para wisatawan menegaskan pentingnya privasi dalam mewujudkan kepuasan mereka, diikuti oleh keselamatan dan keamanan, sedangkan peringkat ketiga diambil oleh "kebersihan". Temuan menunjukkan bahwa wisatawan kurang puas dengan kebersihan kamar mandi hotel dan furnitur kamar.

(Tasci \& Boylu, 2010) mengatakan bahwa 309 responden $(n=309)$ semuanya menjawab puas selama kunjungan wisatawan mancanegara ke negara Turki dan rata-rata tingkat kepuasan wisatawan mancanegara dan nusantara mencapai 7 dari 10 poin skala likert. Penelitian ini juga mendukung penelitian yang dilakukan oleh peneliti bahwa 62 responden atau $68,13 \%$ mengatakan wisatawan mancanegara dan nusantara merasa puas terhadap keselamatan dan keamanan di Desa-Desa Wisata, Indonesia. Sebaliknya, 29 responden atau $31,87 \%$ mengatakan wisatawan mancanegara dan nusantara tidak puas terhadap keselamatan dan keamanan di Desa-Desa Wisata, Indonesia. 


\section{Kesimpulan}

Ada pengaruh kesehatan dan hygiene terhadap kepuasan wisatawan mancanegara dan nusantara. Semakin baik kesehatan dan hygiene, maka semakin meningkat kepuasan wisatawan mancanegara dan nusantara. Aksesabilitas ke air minum dan sanitasi merupakan indikator utama kesehatan dan hygiene apabila dibandingkan dengan indikator lainnya seperti: ketersediaan jumlah dokter dan perawat, fasilitas tempat tidur rumah sakit dan resiko terkena penyakit. Penelitian ini juga mendukung penelitian yang dilakukan oleh penulis bahwa lima puluh tiga koma delapan puluh lima persen mengatakan bahwa wisatawan mancanegara dan nusantara merasa puas terhadap kesehatan dan hygiene di Desa-Desa Wisata, Indonesia. Ada pengaruh keselamatan dan keamanan terhadap kepuasan wisatawan mancanegara dan nusantara. Semakin baik keselamatan dan kesamanan, maka semakin meningkat kepuasan wisatawan mancanegara dan nusantara. Aksesabilitas tujuan wisata merupakan indikator utama keselamatan dan keamanan dibandingkan dengan indikator lainnya seperti: Karyawan yang bersahabat dan baik, tempat desa wisata melindungi barang-barang milik wisatawan mancanegara dan nusantara, kejelasan rambu-rambu dan arahan keselamatan dan keamanan, jalan-jalan di siang hari lebih aman dibandingkan malam hari. Penelitian ini juga mendukung penelitian yang dilakukan oleh peneliti bahwa enam puluh delapan koma tiga belas persen mengatakan wisatawan mancanegara dan nusantara merasa puas terhadap keselamatan dan keamanan di Desa-Desa Wisata, Indonesia.

\section{Daftar Pustaka}

Amir, A. F., Ismail, M. N. I., \& See, T. P. (2015). Sustainable Tourist Environment: Perception of International Women Travelers on Safety and Security in Kuala Lumpur. Procedia - Social and Behavioral Sciences, 168, 123-133. https://doi.org/10.1016/j.sbspro.2014.10.218

Badan Nasional Sertifikasi Profesi. (2020). Skema Pariwisata oleh Badan Nasional Setifikasi Profesi. Badan Nasional Sertifikasi Profesi. https://bnsp.go.id/

Biro Pusat Statistik. (2020). Konsep dan Definisi Statistik Kunjungan Wisatawan Mancanegara. Biro Pusat Statsitik. https://www.bps.go.id/subject/16/pariwisata.html

Castro, J. C., Quisimalin, M., Pablos, C. De, Gancino, V., \& Jerez, J. (2017). Tourism Marketing: Measuring Tourist Satisfaction. Journal of Service Science and Management, 280-308. https://doi.org/10.4236/jssm.2017.103023

Fanani, A. K., \& Maryati. (2019). Pemerintah Targetkan Jumlah Desa Wisata Capai 10 Ribu Pada 2020. Antaranews.Com, 1. https://www.antaranews.com/berita/1008682/pemerintahtargetkan-jumlah-desa-wisata-capai-10-ribu-pada-2020

Imbeah, N., \& Bujdoso, Z. (2018). Tourist safety and security in the Central Region of Ghana overview and case study. Ecocycles, 4(2), 33-45. https://doi.org/10.19040/ecocycles.v4i2.113

Jovanović, S., Janković-Milić, V., \& Ilić, I. (2015). Health and Hygiene Importance for the Improvement of Tourism Sector Competitiveness in Serbia and the South-Eastern Europe 
Countries. Procedia Economics and Finance, 19(15), 373-382. https://doi.org/10.1016/s2212-5671(15)00038-6

Kemenparekraf Republik Indonesia. (2020). Foreign Tourists Data in 2020. Ministry of Tourism and Economy Creative of the Republic of Indonesia. https://www.kemenparekraf.go.id/post/data-kunjungan-wisatawan-mancanegara-bulanantahun-2020

Kementerian Pariwisata dan Kebudayaan. (2011). Peraturan Menteri Pariwisata dan Kebudayaan Nomor: KM.18/HM.001/MKP/2011 Tentang Pedoman Program Nasional Pemberdayaan Masyarakat (PNPM) Mandiri Pariwisata. Kementerian Pariwisata Dan Kebudayaan.

https://www.kemenparekraf.go.id/asset_admin/assets/uploads/media/old_all/2_ PERMEN_TENTANG_PEDOMAN_PNPM_2013.pdf

Kusubandio, W., \& Tanoesoedibjo, A. (2020). Rencana Strategis Kementerian Pariwisata dan Ekonomi Kreatif 2020 - 2024 (1st ed.).

Liliyah, A., \& Rahayu, E. M. (2020, December). Wisata Desa Tinggi Peminat Selama Pandemi, Kemenparekraf Siapkan Pendampingan. Swa.Co.ld, 1.

Manui, J., \& Wongsai, S. (2017). Tourists ' Perceptions on Safety and Security : a Case Study of Phuket Island of Thailand. Proceedings 2nd ISI Regional Statistics Conference, 20-24 March 2017, Indonesia (Session July. https://www.researchgate.net/publication/334591938_Tourists\%27_perceptions_on_safety _and_security_a_case_study_of_Phuket_Island_of_Thailand

Nagaj, R., \& Žuromskaitè, B. (2020). Security Measures as a Factor in the Competitiveness of Accommodation Facilities. Journal of Risk and Financial Management, 13(5), 99. https://doi.org/10.3390/jrfm13050099

OA, A. (2017). Impact of Safety Issues and Hygiene Perceptions on Customer Satisfaction: A Case Study of Four and Five Star Hotels in Aqaba, Jordan. Journal of Tourism Research \& Hospitality, 06(01). https://doi.org/10.4172/2324-8807.1000161

Ramasamy, R. (2013). Impact of Tourist Perceptions, Destination Image and Tourist Satisfaction on Destination Loyalty: A Conceptual Model. PASOS. Revista de Turismo y Patrimonio Cultural, 11(July 2013), 67-78. https://doi.org/10.25145/j.pasos.2013.11.039

Tasci, A. D. A., \& Boylu, Y. (2010). Cultural Comparison of Tourists 'Safety Perception in Relation to Trip Satisfaction. International Journal of Tourism Research, 192(July 2009), 179-192. https://doi.org/10.1002/jtr.745

World Economic Forum. (2019). The Travel and Tourism Competitiveness Report 2019 [EI Informe de Competitividad de Viajes y Turismo 2019]. http://www3.weforum.org/docs/WEF_TTCR_2019.pdf 